\title{
Patronage and Ethnicity amongst Politically Active Young Kenyans
}

\author{
Eija Ranta
}

\section{Introduction}

When I met Garakilo in the sunlit courtyard of the University of Nairobi, this normally calm and prudent young student was simmering with the anger of deep disappointment. Born in the Rift Valley with roots in the north eastern corner of rural Kenyan borderlands, he had always been active in party politics: prior to 2012 in the Kenya African National Union (KANU), Kenya's sole political party during the long one-party state era, and after that, in the National Alliance (TNA), the leading party of the current governing coalition known as the Jubilee Alliance. During campaigning, the TNA explicitly portrayed itself as a youthful party, which gave Garakilo high hopes for the possibility of social change that would benefit Kenya's large but often disregarded majority: the youth. After less than two years from the seemingly successful political victory, his anticipation had, however, turned into mere frustration and, to an extent, anger. He felt that the youth had been bypassed once again. "If, [as a young person in party politics], you don't have money, forget it," he said to me. "Only the thieves will make it," he observed disconsolately as harsh sunlight came out from behind the trees of the patio and briefly blinded him.

John, on the other hand, was of the opposing camp. Born in Western Kenya, he was a youth leader in one of the political parties belonging to the Coalition for Reforms and Democracy (CORD), a conglomeration in the Kenyan parliament opposing the governing regime. Having started his political activism in the Forum for the Restoration of Democracy (FORD-Kenya), which had effectively challenged the one-party rule of the KANU during the 1990s, he portrayed himself as a fierce believer in democratization through party politics. Yet being part of a politically marginalized ethnic group, he felt that what he called the "ethnicization of party politics" was the main reason for their continued presence in the opposition - and a major challenge for the youth of Kenya because, in his opinion, political parties, including those in the opposition, were identified with "the ethnic naming of the leader". Despite 
these challenges, he retained the anticipation of democratic change. I became acquainted with both of these politically active young Kenyans through a youth political network that was supported by the international development donor community.

From the perspective of the emergence of young leaders in the centres of Kenyan politics, the 2013 elections have been perceived as a major success by many (Elder, Stigant and Claes 2014). Uhuru Kenyatta and William Ruto - the elected president and vice-president respectively - explicitly portrayed themselves as representing the fresh and dynamic younger generations of the digitalized social media era against the elderly and stagnated status quo politicians (Muna, Stanton and Mwau 2014, 1390-1391). At the age of 51, Kenyatta was, indeed, the youngest among the Kenyan post-independence presidents in comparison to Mwai Kibaki elected at the age of 71 (2002), Jomo Kenyatta at 70 (1964) and Daniel arap Moi at 54 (1978) (ibid., 1385). More importantly, a relatively large number of young people between the ages of 18 and 35, which is the official definition of youth in the Kenyan constitution (Republic of Kenya 2010, Section 260), were either elected or nominated to the parliament. Kenya's 2010 constitution introduced affirmative action, that is, youth quotas both for the Senate - one young man and one young woman nominated by political parties - and for the National Assembly - twelve seats for youth, persons with disabilities and workers - in order to strengthen the enhancement of the political rights of the youth cohort. With 5.9 per cent of Members of Parliament (MPs) under the age of 30, Kenya became the top country worldwide in the number of youth at the Upper House of Parliament (Inter-Parliamentary Union 2014, 9). An estimated 75 per cent of Kenyans are less than 30 years old, while 39 per cent are aged between twenty and forty-nine (Muna, Stanton and Mwau 2014, 1383). Given the demographic majority of youth in Kenya, this political transformation appears as justified - yet insufficient.

This chapter examines how young people active in party politics portray their hardships and obstacles while trying to enter parliamentary political forums. It discusses how they narrate the complex relationships - and apparent contradictions - between an assumedly youth-friendly political shift and real-life experiences of marginalization on the basis of two issues: political patronage and ethnicity. While political patronage and ethnicity have been widely and exhaustively debated in scholarly literature on African politics, they still resonate strongly in the experiences and narratives of these politically active young Kenyans. Through the examination of these issues, the chapter touches upon the delicate and constantly shifting boundaries between exclusion and inclusion, hopes and despair. 
Methodologically, the chapter draws on interviews with nine young members of political parties, four activists in youth organizations, and one former student politician currently a political strategist for an oppositional political party. ${ }^{1}$ Four of the political party members were women, while the rest were men. However, the chapter is narrated predominantly through the stories of Garakilo and John, ${ }^{2}$ who were exceptionally analytical when elaborating on the importance of the intersectionality between age, class, and ethnicity in Kenyan politics. Their views effectively represented the general feelings among my informants with the exception that they were more self-reflexive about their own political parties. The interviews were conducted during fieldwork in July 2014 and January 2015. I acquired prior knowledge of the issues related to political participation in Kenya during a commissioned research for the Ministry for Foreign Affairs of Finland on its development cooperation programme, which included study of the massive electoral aid provided by the foreign donor community for the 2013 elections (Katsui et al. 2014). The fieldwork for that purpose was conducted during October and November 2013.

\section{Political Patronage among Party Formations}

I interviewed Garakilo in January 2015. He told me that his political career had started as a youth leader in the KANU. From 2012 onwards, however, he had joined the group that supported the presidency of Uhuru Kenyatta who subsequently, formed the TNA for that purpose. Why had he then become so disappointed so soon after the TNA had won the elections? One incident that explains it partly had happened in his community of origin. As a member of the TNA, Garakilo had had an interest in standing for parliament in the 2013 elections. However, he had been asked by the leaders of his community - all male and much older than himself - to step down and to make way for a senior candidate. As all decisions related to politics were made in these male elders' community meetings, "What they say is what will go on and will be accepted by all community members", he stated. He concluded that although many younger people tend to have more education and experiences outside

1 Although this chapter focuses on youth in political parties, it is acknowledged here that much youth political activism in Kenya occurs outside formal parliamentary forums including such 'legitimate' forums as NG Os, mainstream churches, student unions, and sports clubs, as well as politically more contradictory arenas such as charismatic religious movements, militias and gangs (Frederiksen 2010, 1079).

2 These are pseudonyms. 
the community than the elders, "[They] have a disadvantage, because they do not have a say in [community] meetings: it is a taboo to talk in front of the elders". Through his participation in the TNA activities, he had searched for an opportunity to change this pattern. However, his real-life experiences inside the party did not live up to his expectations, as the following excerpt from the interview with Garakilo demonstrates:

When I joined the TNA, most of the campaign and the policies that we used in TNA was that it is a youthful party. Although the leadership of the party was just chosen not elected, most of them were young people who are thirty years and below. But we discovered that this was just used for [a] short time before the elections. And immediately after the elections, these young people who were given different tasks in the party, they are not there anymore. They are there just by name ... So we discovered that this was another trick that is used by politicians, to use the name of the youth before the elections, and immediately they won the elections, most of the young people who engineered everything in the social media, in the campaign and everything, are no longer there ... Most of the youth in Kenya are used by politicians, they'll come and they'll give you all the opportunities before the elections, but once the elections are done and they got what they want, then the youth are no more: they are not involving them in the decision making, they are not asked anything ... And it's not only in one-party, it's the same thing in all the political parties ... Things change immediately after elections, completely ... Even the leadership will pretend to be very democratic and everything before elections and turn out to be very tough dictator in everything immediately after the elections are won.

Thus, Garakilo felt that, in the practice of national politics, he was experiencing similar patterns of exclusion as in local politics, despite the promises to the contrary. The TNA party politics seemed to include young men and women in their activities during political campaigning, but when the party had obtained decision-making powers the presence of the youth seemed to vanish. Garakilo's narrative also reflected a discrepancy between pre-election and postelection times in terms of hope and pessimism. There was a hope for change during the pre-election era and a disappointment afterwards.

Garakilo's feeling of being "used" by elderly decision makers, whether community leaders or politicians, was widely shared by many young Kenyans active not solely in formal party politics but also in NGOs and activists groups. Many of them identified this with the phenomenon of political patronage widely 
discussed in the academic literature on African politics and state formation. Starting with the well-known work on neopatrimonialism by Chabal and Daloz (1999), political patronage has been associated with the exercise of patrimonial power in Africa. As a contrast to modern, rational-legal bureaucracies, patrimonialism in Weber's sense refers to a type of state formation which is centred on the male ruler and his family. Stretching this to the context of modern Kenyan state formation, neopatrimonialism refers to the running of the postcolonial state through patron-client networks, where the president or some other major political leader (patron) distributes state resources, such as land, state contracts, and development projects, to his allies (clients) (Sundet and Moen 2009, 6). The logic behind this reciprocal patronage system is that "the distribution of material resources and the manipulation of state actions in favour of clients are important ways that patrons can increase their power and entrench their positions of influence" (Matter 2010, 69). Consequently, "rather than using their control of institutions like parliament, the presidency or the judiciary to protect Kenyans and their livelihoods, elites in power have tended to use their power to seize resources" (Branch 2011, 21-22).

In the case of his own community, Garakilo admitted that many perceived that if an elderly person were elected to the parliament, he would have more authority and wealth to "give stuff", such as water or pasture, to community members than he as a young university student would be able to do. This situation occurs because, as one civil society activist noted: "Even if you don't directly bribe people, you need to be shown as conducting harambees; ; those who do more harambees, stand better chances of being elected". This implies that instead of the state or municipality functioning as a redistributive agent, the distribution - or non-distribution - of resources is seen by community members to be strongly dependent on individual political leaders and their networks (Branch 2011). As a result, people tend to direct their support, and opt to become part of the patron-client networks, of the wealthier ones. Garakilo had made the same observation. He further demonstrated how hard it is for young persons who have ideas but no resources to compete in the environment of these patron-client networks, as he told me in the interview:

In an election year, you'll find a lot of money around. Everybody who wants to contest will come and look for a group of youth, "Where do you guys vote? Where do you guys stay? This place, this place", and give you a

3 Swahili notion of 'working together'; established as a national slogan in Kenya by the first post-independence regime. 
few thousands of shillings to share among the group. People will vote the people from whom they got money. So, there is this young person who is just selling ideas and policies he thinks he will implement after being elected and then this other guy is giving out money throughout: when you are sick, you'll find him in the hospital to pay for your hospital bill; he is going to schools making donations, buying probably a school bus. So, people [draw a conclusion] that if this guy is giving us all this money now, it will be even much better when he is elected. But what they don't realize is that, immediately after being elected, he starts trying to recover the money he used in the elections, through dubious means, by taking public funds. From public funds he is taking back the same money that he used for the elections, and even more for [financing] the next election [campaigns]. So the issue is that you will find that many youth, who are interested in politics, are held back because they don't have money.

Garakilo's views of the importance of money - or its lack - in Kenyan politics were shared by many politically active young men and women. An activist from a Nairobi-based NGO suggested that in Kenya, political parties have not historically started as peoples' movements or social movements, but rather as personal creations of what he called the "moneyed-old". Former student politician and a political strategist for one oppositional political party, on his part, alleged that "Kenyan political party formations emerge from individuals, who are rich and have the resources to run the political machinery". This is apt to lead to political patronage, because it "comes from how much you have originally contributed to the party", as one aspiring youth leader in an oppositional party noted. In regards to the possibilities of young men and women to emerging as candidates in the parliamentary elections, "How close you are to the leader", he continued, "affects your nomination". Many of those who have been able to enter into politics might be perceived as having been successful in, as the activist from youth NGO commented, "allying with the old who run political parties". This resembles Frederiksen's $(2010,1079)$ remark that in addition to NGOS, churches and ethnic associations, youth politics may take place in "party-political movements closely associated with 'big men', particularly active at elections".

Consequently, although Garakoli admitted that there were young men and women who had been able to enter into parliamentary politics through their ideas rather than money, especially in major cities such as Nairobi, it was difficult for him to perceive them as agents of change. He felt that it was extremely difficult for young people to become active political subjects through other means than by conforming to the rules of political patronage. In regards to 
this, the above mentioned political strategist commented to me in the same lines:

If we talk about youth participation, to be honest with you, they come more as appendixes to rich persons ... Most political formations ... are more or less closed clubs of few individuals, sometimes even one individual. Throughout the history of party life from 1992 up to now, you can see youth as being used ... The person who has the money; the financial power, is the person who will have the loyalty of the youth. I refuse to call it youth participation: it is youth co-option. Most youth that will find themselves in political office, are those youth who enjoy good will not so much from the political voter but enjoy the good will of the owners of political [parties]. Mostly [the youth] are political and ideological extensions of political elites...

What he seems to be suggesting here is that there appears to be a tendency in Kenyan party politics for politically active young people to be co-opted into complex networks of political patronage by wealthy political figures. Following the same line of thinking, it has been remarked that "like ethnicity, generational identities have been manipulated and instrumentalized by Africa's patrimonial elite" (Kagwanja 2005, 53). In a situation in which the distribution of state, municipal, and other resources is dependent on individual political leaders rather than formal, institutionalized mechanisms through which benefits and services are circulated, it appears to be difficult for young women and men to challenge the logics of political patronage. In the following, I will add the dimension of ethnicity to the discussion.

\section{Mastering Ethnic Networks}

I met John for the first time in a capacity building event organized jointly by a Washington-based, democracy-promoting NGO and a Nordic development NGO whose objectives included, among others, the enhancement of youth political participation and the strengthening of political parties. There were approximately forty participants from various political parties in this "interparty forum for the youth". John was representing his political party in which he served as the national youth leader and a member of its management committee. He had striven to become a candidate in the 2013 parliamentary elections but had, to his disappointment, lost to a fellow party member. However, 
he had not lost hope but was rather determined, if resources would allow, to run as a candidate for the parliament in the elections in 2017.

When I later met John at his party's office, our discussions touched upon political patronage, to which he brought a new dimension. The major issue that he wanted to tackle during the interview was ethnicity and its significance for party politics in Kenya. He perceived "the ethnicization of political parties" as the major problem because, in his opinion, "You can't build political parties as institutions, as instruments of governance, because as they stand now they are like ethnic blocks without ideology". He suggested in the interview that, "Most political parties [are formed] on the basis of individuals leading those parties. For instance, if a political party is formed and lead by a person from my community, then I make it my political party..." Garakoli had addressed this same phenomenon in our interview by calling political parties "private companies". Thus, he listed that the TN A belonged to Uhuru Kenyatta, the United Republican Party (URP) to William Ruto and the Orange Democratic Movement Party (ODM) to Raila Odinga, the main opposition leader. He perceived them as patrons governing and controlling party politics within the Kenyan political landscape. Political patronage appears to be intimately linked with ethnic affiliation because, as John, on his part, noted, "The leader of the political party is like the king of the tribe or ethnic group". Kenyatta, Ruto and Odinga, it was noted, represent the Kikuyu, the Kalenjin and the Luo communities respectively. Curiously enough, in the case of Garakoli his ethnic background did not correspond with that of the TNA. In fact, the same applied to two other youth politicians from the governing coalition with whom I interacted. While their discourses about Kenyan politics were saturated with references to ethnicity, their own ethnic origins did not correspond with those that they themselves identified with the governing regime but rather with those of the politically marginalized opposition.

It is well-known that colonialism was instrumental in trying to encapsulate fluid social identities into ethnically fixed categories as part of its divide and rule policies (Kakai 2010; Karega-Munene 2010; Zeleza 2014). According to Mamdani (1996), the colonial state created ethnically based authoritarian governing mechanisms. In Kenya, European settlements were established as buffer zones in order to protect the British monopoly over the fertile Kenyan highlands and to weaken historically vivid intermingling among local communities (Kakai 2010, 37). Furthermore, each group was assigned specific labour positions (for example, the Kikuyu worked in the fields, the Luo were domestic servants), which further intensified ethnic categorization (ibid., 37-38). While the decolonization process was firmly grounded on nationalist discourses of unity and development, the silencing of political spaces and the shift towards 
one-party state gradually caused ideological debates to wither away. Instead, as Zeleza $(2014,26)$ has noted, "ethnic mobilization and contestations assumed greater salience". Ideological battles between pro-West conservatives and socialist radicals were transformed into hostilities and rivalry, mainly between the Kikuyu and the Luo, the former governing the centralized state power. Although Moi, Kenya's dictatorial ruler for nearly 25 years, stressed the importance of Kenyan nationalism, he appointed members of his own ethnic group (the Kalenjin) into state positions that were previously held by the Kikuyu during the presidency of Kenyatta (Kakai 2010, 42). Subsequently, the Kikuyu and the Kalenjin have dominated the Kenyan political scene, while other groupings have remained predominantly in the political opposition. ${ }^{4}$ This has had concrete political-economic consequences, because it has been shown that in Kenya, both the distribution of state resources and the appointment of state officials have systematically favoured the ethnic community of the ruling president (Hulterström 2007; see also Nyanchoga 2014). In relation to this, one young man from an oppositional party aspiring to enter parliament noted to me, "The stakes are very high, because people know that if you win, your people will benefit".

John, together with many other politically active young Kenyans, perceived that ethnic politics was a major problem for the youth because senior male politicians and community leaders have a very strong hold on the governing and controlling of ethnically determined patron-client networks. Some said that sometimes party leaders seemed to think that the right time for the youth to enter into politics came solely when 'their grandfathers' networks have expired". The case of the current president illustrates the point. Perceived as a young and fresh candidate, he was, at the same time, perceived by many as the legitimate heir of his father's political legacy. Thus, he was considered by many as having inherited his father's ethnic networks and the position as the representative of the Kikuyu community, although not without ambiguities. For those young men and women without ties to existing political family dynasties, the opportunities were few, as John told me:

If political parties are identified on basis of ethnicity and the ethnic naming of the leader, then they are so closed and political space is very, very narrow. And if the political space is narrow, then it's very difficult for young people without resources to penetrate that narrow stream

4 It is often proposed that there are 42 ethnic groups in Kenya, the largest in number being the Kikuyu, Luhya, Luo, Kalenjin, Kamba, Kisii, Mijikenda, Somali and Meru (National Council for Population and Development 2013, 7). 
to advance to senior political positions ... This ethnic basis of political parties gives normally preference to [such] old people with money who support the interests of the party. They are given certificates and party positions. But for young people just struggling we don't have resources, we don't have nothing apart from our brains and time.

According to John, this exclusion had been historically constructed.

During the ruling KANU era, most young people worked as youth-wingers; you were like the foot soldiers of the party. You were not given any role; your role was just to protect the party interests. When the party leaders wanted to go to a certain area, it was the youth-wingers who were given weapons, you see, to protect them. That narrative has continued to affect youth leadership, because till now, if you say that you are a youth leader of a party you are associated with being a youth-winger, and not with the institution in which you could do policies and contribute to the party. You are seen just as a security man for political parties. And that is killing the motivation for most young people to venture into politics.

During the one-party era, intergenerational division of labour tended to place youth predominantly in informal and illegitimate political spaces, while formal political arenas were occupied by the so-called 'Old Guard', "those believed to be unwilling to change and accept new ideas" (Muna, Stanton and Mwau 2014, 1378). Jomo Kenyatta, for example, used the youth wings of the KANU to weaken political rivals, while Moi employed them for political terror and extortion (Kagwanja 2005, 55). Accordingly, Kenyan political scientist Adams Oloo (2010, 150) has stated that "all elections during the one-party era witnessed violence meted out by youth-wingers, with prominent politicians hiring them to harass and disrupt their opponents' rallies".

John told me that, in his opinion, ethnic politics is the major cause for political violence in Kenya, "If you belong to another community then after elections if your community won, [other communities] are attacking you saying that you stole my victory". He concluded, "That is the basis for most conflicts and political violence in Kenya, because every community wants to lead". Indeed, except for the 2002 elections, organized violence, such as the use of youth militias to intimidate opposing candidates and sexual violence against women candidates and voters, has been part of all elections in Kenya (Sundet and Moen 2009, 10). In 2007, the post-electoral violence led to more than 1,200 deaths and the displacement of hundreds of thousands of people (Office of the High Commissioner for Human Rights 2008, 5). Violence, torture 
and killings, although occasionally spontaneous, were systematically organized and financed by politically and economically affluent senior male politicians and conducted by youth militias, youth gangs and sometimes police officers and military personnel (Sundet and Moen 2009, 10-11). Even after the post-electoral violence and the realization of the urgent need to open up formal political forums for the youth, it was the older generation that was "fast to seize power behind closed doors and got away with the significant [governmental] positions" (Muna, Stanton and Mwau 2014, 1390).

Ethnicity, or what Lonsdale (1994) calls 'political tribalism', has arguably been one of the key drivers of politics in Kenya. It has even been suggested that political parties in Kenya, even more so than elsewhere in Africa, are predominantly organized by ethnic groups rather than ideological differences, class concerns or occupational matters (Hulterström 2007). Kinship and lineage based collectivities, community organizations and ethnic identification are not important solely for identity construction and the sense of belonging but also for economic survival. As Branch (2011, 293-294) has suggested, ethnicity is not the cause but a symptom of a weak sense of nationhood and a non-redistributive state that does not even out the colossal gaps between narrow elites and the poor masses. In contexts where state formation processes have been constructed through colonial conquest and violence as well as various forms of neocolonial dependency relations, people tend to identify with other kinds of collectivities rather than with the state. Branch $(2011,293)$ continues that what ethnicity brings to the people is what the state does not: trust.

In the absence of redistribution, ethnicity provided a way in which Kenyans could access and protect the scarce resources of land, jobs and political power. The networks of kin encouraged by ethnicity provided for access to plots of land, work and housing on a reciprocal basis. The networks of patronage meant that, if their political leader became an MP or a minister (or even president), then the roads in their district might be repaired, the moribund local factory rejuvenated or the village school expanded. Ethnicity was not irrational and nor was it an expression of traditionalism; instead it was a logical response to an experience of the modern world in which resources are scarce...

BRANCH 2011, 294

Consequently, "ethnic identification keeps together a 'moral community' which often, and especially in times of crisis, provides support and functions as the sounding board for communal values and experience" (Frederiksen 2010, 1074). Yet, at the same time, the "politicization of ethnicity has been a key technique 
used by the changing political regimes and elites first in colonial, then in postcolonial Kenya" (ibid., 1073). Branch (2011, 16-17) has suggested that elites have encouraged political identification and action first and foremost through ethnicity, "in order to crush demands for the redistribution of scarce resources". In other words, ethnicity is used by elites and other groups in order to avoid addressing larger structural issues connected with poverty and inequality, namely, those related to the redistribution of lands, means of production, jobs and political power.

The way public resources are distributed through patrimonial relationships, that again generate ethnic divisions, seems to link the accounts of these two young men. An institutionalized state apparatus that is driven by civil servants and policies is the missing link here, I would argue, rather than just possibilities for the young to participate. A public sector that is truly democratic rather than patrimonial might be what is needed before young aspiring politicians have a real chance, regardless of class or ethnic belonging. Based on my interviews, unfortunately the training workshops organized by the NGOs also focus on the capabilities of individual youths but overlook the structural and institutional issues of the public sector which seems to enable or hamper youth participation, and cause so much frustration.

\section{Conclusions}

This chapter has investigated how politically active young Kenyans describe and understand the difficulties that they face when they participate in party politics and are struggling to find a way into parliamentary political forums. Although already widely discussed in academic literature on African politics, I chose to focus on the topics of political patronage and ethnicity because of their overwhelming presence in the narratives of those politically active young Kenyans with whom I interviewed and interacted. By focusing especially on the narratives of Garakilo and John, this chapter has showed that despite the assumedly youth-inclusive political shift, young people active in party politics continue to experience various forms of obstacles and exclusions in their political careers.

Through Garakilo's discussion of political patronage one is tempted to reach the conclusion that as long as the distribution of state, municipal and other resources is dependent on individual political leaders rather than formal, institutionalized mechanisms through which state benefits and services find their ways to citizens on an equal basis, it will be difficult for young people to challenge the logics of political patronage. And, at the moment, as Ake $(2003,116)$ 
has put it: "the state is not so much a reality as a hope..." While party politics has opened up forums for youth political engagement and inclusion, especially in pre-electoral periods, young men and women have hard time breaking through to positions of power due to their lack of resources and political authority both at local and national political levels. Unless already intertwined in political networks through family ties, young people have little room for manoeuvre in party politics without the protection of wealthy political patrons. Until state resources are distributed in an institutionalized manner rather than on patrimonial principles, young political leaders, when they finally enter political positions of power, risk becoming exactly like their elders, because the room for change seems so narrow and unrealistic. The capacity-building workshops organized by the NGOs could be an arena where this is tackled realistically and across party lines, as it frustrates youth regardless of party affiliation. Yet structural issues have to be discussed in training sessions as well.

The other side of the coin of political patronage is the co-option and manipulation of youth for the purposes of serving the interests of party elites. They are most often senior male leaders of their respective ethnic groups. Ethnicity forms an important source of identity and establishes a sense of belonging to a collectivity. Yet throughout Kenyan history, from colonialism to contemporary centralized presidentialism, there have been attempts by those in power to congeal fluid identities into fixed ethnic categories in order to serve elite interests: to protect and to accumulate wealth and to obstruct any attempts at challenging elite privileges ideologically and through structural reforms. Through John's views on ethnicity in Kenyan politics it was demonstrated that in this kind of political situation young men and women tend to be co-opted into ethnic networks. Instead of allying with other youth on the basis of common issues or ideology, they are used by senior party leaders to agitate ethnic hatred and violence against each other.

However, this was not the whole truth. As mentioned earlier, while politically active young Kenyans talked a lot about the importance of ethnicity in politics, three of my informants did not in fact belong to the parties that were most closely identified with their ethnic backgrounds. All of them came from politically marginalized ethnic groups, but were now supporting either the TNA or the URP, leading parties of the governing regime. It is difficult to say whether this signalled political opportunism towards those in power or whether it hinted that while ethnicity played a major role in political discourses as a categorically stagnant concept, it was performed fluidly in the everyday political practices of young Kenyans. Ultimately, youth lives appeared more complex than their discourses. 
So, what will the future hold for such politically active young Kenyans as Garakilo and John? They were both hoping that issues other than money or ethnicity would determine the course of future politics in Kenya. They were expecting that in the future, Kenyan political parties would become formally organized and transparent institutions in which leadership positions would rotate democratically among all interested party members. Garakilo, who had had the experience of his party winning the elections, was, however, quite sceptical about whether these dreams would ever be realized. He perceived the youth to be as equally ethnically divided as older generations and considered ethnicity to be very deeply inscribed in Kenyan politics. However, despite all the disappointments he had faced in his own community and at national political forums, his last remark to me was that he might, nevertheless, consider contesting in the next elections. This showed that he still cherished a spark of hope for change.

John, for his part, was hopeful all the way. So far his party had been unsuccessful in winning parliamentary and presidential elections. Consequently, he still had the anticipation that, if that day comes, his party would do things differently. He was, however, fearful of political violence. He felt that the resentment caused by constant exclusion of young men and women in general - and more specifically of those belonging to politically marginalized ethnic groups and the political opposition - was a real danger. To avoid this, he tried to engage himself in constant dialogue between young men and women from other political parties and ethnic groups. And he was convinced that when he ruled, hopefully from the 2017 elections onwards, he would do things differently.

\section{References}

Ake, Claude. 2003. Feasibility of Democracy in Africa. Dakar: Council for the Development of Social Science Research in Africa (CODESRIA).

Branch, Daniel. 2011. Kenya: Between Hope and Despair, 1963-2012. London: Yale University Press.

Chabal, Patrick and Jean-Pascal Daloz. 1999. Africa Works: Disorder as Political Instrument. Oxford: Currey.

Elder, Claire, Susan Stigant, and Jonas Claes. 2014. Elections and Violent Conflict in Kenya. Making Prevention Stick. Washington: United States Institute of Peace \& Constitution and Reform Education Consortium (CRECO) \& Interparty Youth Forum. 
Frederiksen, Bodil Folke. 2010. "Mungiki, Vernacular Organization and Political Society in Kenya”. Development and Change 41 (6): 1065-1089. doi: 10.1111/j.1467766o.2010.01 670.x

Hulterström, Karolina. 2007. "The Logic of Ethnic Politics: Elite Perceptions about the Role of Ethnicity in Kenyan and Zambian Politics." In Political Opposition in African Countries: The Cases of Kenya, Namibia, Zambia and Zimbabwe. Discussion Paper 37, edited by Karolina Hulterström, Amin Y. Kamete and Henning Melber, 7-38. Uppsala: Nordiska Africa Institute.

Inter-Parliamentary Union. 2014. Youth Participation in National Parliaments. Geneva: Inter Parliamentary Union.

Kagwanja, Peter Mwangi. 2005. “Power to Uhuru': Youth Identity and Generational Politics in Kenya's 2002 Elections". African Affairs 105 (418): 51-75. doi: 10.1093/afraf/ adio67

Kakai, Pius Wanyonyi. 2010. "Historicizing Negative Ethnicity in Kenya". In (Re)membering Kenya. Vol. 1 Identity, Culture and Freedom, edited by Mbũgua wa-Mũngai and George Gona, 32-49. Nairobi: Twaweza Communications.

Karega-Munene. 2010. "Production of Ethnic Identity in Kenya". In Ethnic Diversity in Eastern Africa: Opportunities and Challenges, edited by Kimani Njogu, Kabiri Ngeta and Mary Wanjau, 41-54. Nairobi: Twaweza Communications.

Katsui, Hisayo, Eija M. Ranta, Sisay A. Yeshanew, Godfrey M. Musila, Maija Mustaniemi-Laakso, and Alessandra Sarelin. 2014. Reducing Inequalities: A Human Rights-Based Approach in Finland's Development Cooperation with Special Focus on Gender and Disability. Turku/Åbo: Institute for Human Rights, Åbo Akademi University.

Lonsdale, John. 1994. "Moral Ethnicity and Political Tribalism". In Inventions and Boundaries: Historical and Anthropological Approaches to the Study of Ethnicity and Nationalism, edited by Preben Kaarsholm and Jan Hultin, 131-150. Roskilde: International Development Studies, Roskilde University.

Mamdani, Mahmood. 1996. Citizen and Subject: Contemporary Africa and the Legacy of Late Colonialism. Princeton: Princeton University Press.

Matter, Scott. 2010. "Clashing Claims: Neopatrimonial Governance, Land Tenure Transformation, and Violence at Enoosupukia, Kenya". PoLAR: Political and Legal Anthropology Review 33 (1): 67-88. doi: 10.1111/j.1555-2934.2010.01093.x

Muna, Wilson K., Anne Stanton, and Diana M. Mwau. 2014. "Deconstructing Intergenerational Politics between the 'Young Turks' and 'Old Guards' in Africa: An Exploration of the Perceptions on Leadership and Governance in Kenya." Journal of Youth Studies 17 (10): 1378-1394. doi: 10.1080/13676261.2014.918248

National Council for Population and Development. 2013. Kenya Population Situation Analysis. Nairobi: National Council for Population and Development and the United Nations Population Fund. 
Nyanchoga, Samuel Alfayo. 2014. Citizenship, Ethnicity and Politics of Belonging in Kenya. Nairobi: CUEA Press.

Office of the High Commissioner for Human Rights. 2008. Report from OHCHR Fact-Finding Mission to Kenya. 6-28 February 2008. Geneva: United Nations High Commissioner for Human Rights.

Oloo, Adams. 2010. "Marginalisation and the Rise of Militia Groups in Kenya: The Mungiki and the Sabaot Land Defence Force." In Militias, Rebels and Islamist Militants: Human Insecurity and State Crises in Africa, edited by Wafula Okumu and Augustine Ikelegbe, 147-180. Tscwane: Institute for Security Studies.

The Republic of Kenya. 2010. The Constitution of Kenya. Nairobi: National Council for Law Reporting with the Authority of the Attorney General.

Sundet, Geir, and Eli Moen. 20og. Political Economy Analysis of Kenya. Norad Report 19/2009 Discussion. Dar es Salaam and Oslo: Norwegian Agency for Development Cooperation.

Zeleza, Paul Tiyambe. 2014. "The Protracted Transition to the Second Republic in Kenya". In Kenya: Struggle for a New Constitutional Order, edited by Godwin R. Murunga, Duncan Okello and Anders Sjögren, 17-43. London: Nordic Africa Institute and Zed Books. 